\title{
Identifying Riparian Areas of Free Flowing Rivers for Legal Protection: Model Region Mongolia
}

\author{
Purevdorj Surenkhorloo ${ }^{1, *}$, Chimeddorj Buyanaa ${ }^{1}$, Sanjmyatav Dolgorjav ${ }^{2}$, Chimed-Ochir Bazarsad ${ }^{3}$, \\ Batjargal Zamba ${ }^{4}$, Sainbuyan Bayarsaikhan ${ }^{5}$ and Michael Heiner ${ }^{6, *}$
}

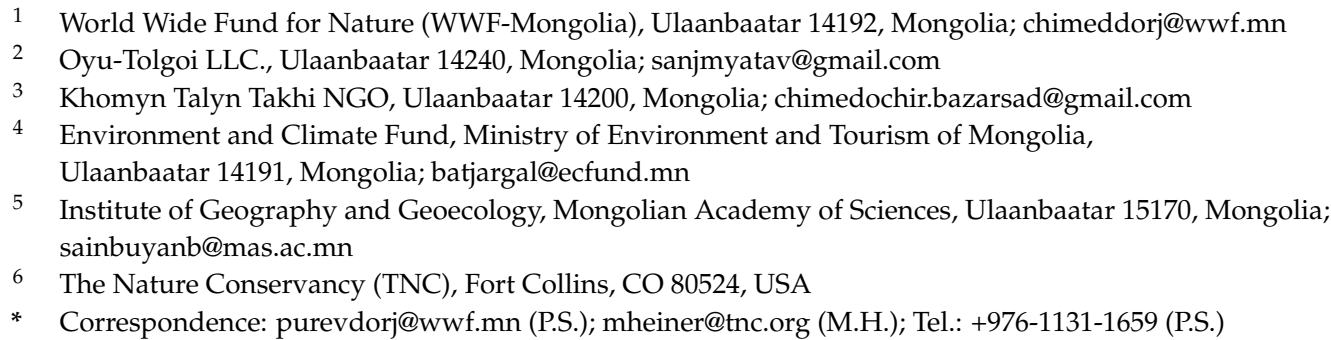

Citation: Surenkhorloo, P.; Buyanaa, C.; Dolgorjav, S.; Bazarsad, C.-O.; Zamba, B.; Bayarsaikhan, S.; Heiner, M. Identifying Riparian Areas of Free Flowing Rivers for Legal Protection: Model Region Mongolia.

Sustainability 2021, 13, 551

https://doi.org/10.3390/su13020551

Received: 30 November 2020

Accepted: 2 January 2021

Published: 8 January 2021

Publisher's Note: MDPI stays neutral with regard to jurisdictional claims in published maps and institutional affiliations.

Copyright: (c) 2021 by the authors. Licensee MDPI, Basel, Switzerland. This article is an open access article distributed under the terms and conditions of the Creative Commons Attribution (CC BY) license (https:/ / creativecommons.org/licenses/by/ $4.0 /)$.

\begin{abstract}
Mongolia has globally significant biodiversity and pastoral traditions, and scarce water resources on which wildlife and people depend. Rapid growth of the mining sector is a threat to water resources and specifically river riparian zones. Mongolia has passed progressive laws for water and habitat conservation, including establishment of Integrated Water Resource Management (IWRM) and river basin governance organizations, and laws protecting the river riparian zone, but implementation has been hindered by limited technical capacity and data-scarcity, specifically because consistent, accurate maps of the riparian zone did not exist. To address this gap, WWF-Mongolia and partners developed a national delineation of riparian areas based on a spatial model, then validated this with local river basin authorities and provincial governments to designate legal protection zones. As a result, 8.2 million hectares of water protection zones including riparian areas have been legally protected from mining and industrial development in the globally significant landscapes and riverscapes of the Amur, Yenisey, and Ob Rivers headwaters, the Altai Sayan ecoregion, and the GobiSteppe ecosystem. These findings demonstrate a pathway for implementing broad-scale, durable legal protection of riverine wetlands through a data-driven, participatory process.
\end{abstract}

Keywords: riparian areas; riverine wetlands; wetland delineation; legal protection; Mongolia; mitigation

\section{Introduction}

The pace of global freshwater biodiversity decline and wetlands loss has reached a crisis [1-3]. Riverine wetlands are a critical component of freshwater systems, performing important hydrologic, geomorphic, and biological functions including pollution and sediment control [4,5], providing vital habitats for biodiversity, and are one of the world's most rapidly declining habitat types [6,7]. River conservation faces a problem of scale, requiring coordinated management at the watershed level [8]. One key conservation strategy is to increase and improve protection [1,2]. However, this must consider local protection of floodplains and riverine wetlands as well as connectivity upstream $[9,10]$.

Mongolia supports globally significant biodiversity and cultural heritage that depend on scarce water resources in an arid landscape. These water resources, as well as the wildlife and pastoral livelihoods that depend on them, are threatened by unsustainable exploitation and pollution, and in particular by rapid growth of mining and related infrastructure [11,12]. The Mongolian government has developed progressive policies and regulations for protection of water resources and habitats but faces the combined problems of rapid development, limited technical capacity, and data scarcity. Here, we describe the 
successful legal protection of riverine wetlands and riparian areas at a basin level, across multiple sectors and political borders, through a data-driven, participatory process.

Mongolia contains the headwaters of three major basins in Central Asia. The Amur River Basin drains eastern Mongolia, crossing China and Russia to the Pacific Ocean. The Amur River Basin is one of the world's ten largest rivers, with globally significant biodiversity including 18 endemic fish species, long distance fish migrations along the mainstem, and floodplain wetlands that support diverse terrestrial flora and fauna [13,14]. Major headwater rivers in Mongolia are the Onon, Ulz, Khalkh, and Kherlen, draining 12\% of the country and carrying 15\% of its runoff. The Khalkh and Kherlen Rivers feed Buir Lake in Mongolia and the Dalai Lake in China, respectively, both Ramsar sites.

The Orkhon and the Selenge Rivers are headwaters of the Yenisey River basin that drains north to the Arctic Ocean. This basin covers $20 \%$ of the country and carries $50 \%$ of the runoff. The Selenge flows into Lake Baikal in Russia, the world's second largest freshwater lake. Rivers here support healthy populations of globally endangered and vulnerable fish species, e.g., Taimen (Hucho taimen), the world's largest salmonid.

The remaining $68 \%$ of Mongolia is in the Central Asian Internal Drainage Basin. Major rivers are the Khovd, Zavkhan, and Bulgan that flow out of the Altai and Khangai mountains across a series of arid endorheic basins, forming wetlands important for endangered migratory water birds that include 19 Important Bird Areas [15]. This area contains the southern part of the Altai-Sayan ecoregion, listed by the Global 200 [16] and Millennium Ecosystem Assessment as globally significant for intact landscapes, biodiversity including high plant endemism, and diverse cultural heritage [17] (Figure 1).

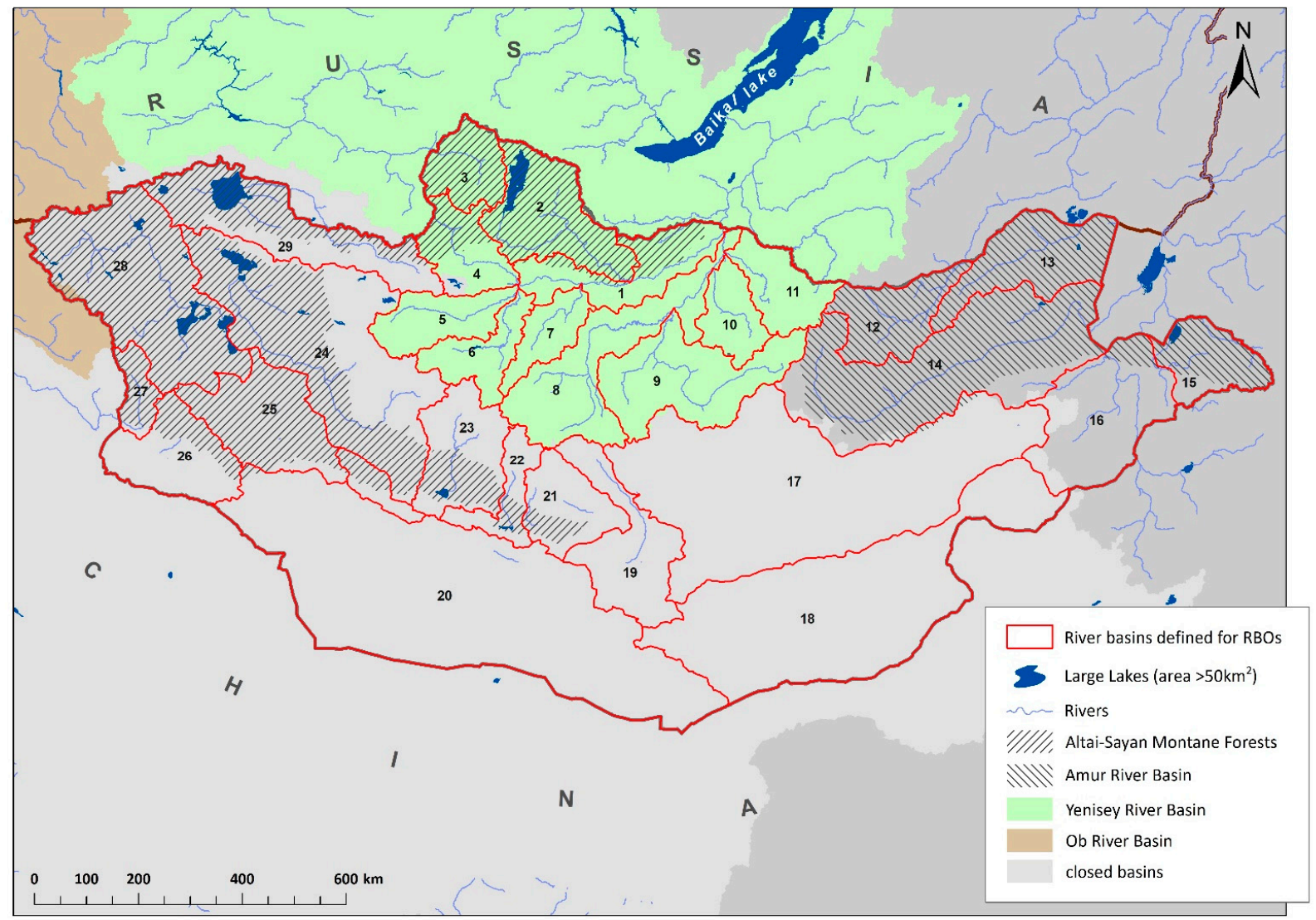

Figure 1. River basins of Mongolia. As shown here, Mongolia contains headwaters of three continental basins and contains 29 river basins for which river basin organizations have been established.

Mongolia also contains the largest steppe ecosystem in the world that supports its historic wildlife assemblage and large wildlife migrations [18], as well as traditional no- 
madic pastoralism. Mongolian temperate grasslands are part of the most converted and least protected biome on the planet [19]. Parts of Mongolia have been identified as among the world's largest and most intact (least converted) remaining wild areas [20,21].

Mongolia has a cold, arid, continental climate. Temperatures range from below $-40^{\circ} \mathrm{C}$ in January to over $30^{\circ} \mathrm{C}$ in July in the Gobi Desert [22]. In the rain shadow of the Himalayas, mean annual precipitation ranges from less than $40 \mathrm{~mm}$ in extreme arid areas to over $400 \mathrm{~mm}$ in northern mountain ranges [22] and is highly variable interannually, with some areas not receiving any measurable precipitation for years at a time [23].

Following transition from a Soviet to a market economy in the 1990s, the mining sector has grown rapidly, and accounted for over 20\% of Mongolia's GDP between 2016 and 2018 and $86 \%$ of exports in 2018 [24]. The impacts of mining on rivers and stream are well documented [25-28]. In Mongolia, many mines are placer mines that take minerals from alluvial deposits, which degrade riverbed morphology, increase sediment/turbidity and nutrients particularly phosphorous, and are difficult to restore [25,26]. Small mining operations, including illegal mining for gold, are widespread, typically in streams and riverbeds [27]. Yadamsuren [28] found a strong relationship of aquatic macroinvertebrate diversity to environment conditions in Mongolian rivers, and significant declines in functional diversity related to water quality degradation.

Mongolia has passed a series of progressive laws for the protection of water resources and implemented IWRM, but implementation is limited by data scarcity (consistent delineation of water protection zones), staff technical capacity (skills, equipment), and budgets [12,29]. The 2009 law, named the "Law on Prohibiting Mineral Exploration and Mining within Protection Zones of Headwaters for Rivers and Streams and Water and Forest Resources Land", and referred to as the "long name law", prohibits mineral exploration and mining within areas designated as protection zones of water bodies. To ensure enforcement, the national government later passed two resolutions for designating boundaries [30,31].

The 2012 amended water law further defined the water protection zone as two zones, "ordinary" (general) and "special" (strict) for the water resources land, to be delineated by national, aimag (province), and soum (county) level governments, and with prohibited activities regulated by the Protection Zone Regime Regulation [32]. The ordinary protection zone is up to $200 \mathrm{~m}$ from the bank of a river, stream, or natural spring. Prohibited activities include tree and shrub cutting, construction of buildings without wastewater treatment, storage of petroleum, chemicals, radioactive materials, fertilizers, and pesticides, and discharge of wastes and pollutants. The special protection zone is within $50 \mathrm{~m}$ from the bank of a river, stream, natural spring, or floodplain, or may extend the length of riparian area; and within at least $100 \mathrm{~m}$ from a lake or other water bodies. In the special protection zone, prohibited activities include mineral exploration and mining, gravel or stone mining, any construction of buildings and facilities, agricultural cropping and timber harvest.

To strengthen river basin governance and create more participatory and coordinated water resource management decisions, the 2012 Water Law also established and funded river basin organizations (RBOs) for 29 major river basins across Mongolia [33] (Figure 1). RBOs consist of a River Basin Authority (RBA) and a River Basin Multi-Stakeholder Platform Council (RBMSPC) organized around river basins rather than political boundaries [29]. RBAs are government authorities of professional staff that coordinate decisions and activities across aimag (provincial), and soum (county) levels of government, while RBMSPCs are participatory stakeholder bodies representing government, NGOs, local communities, and industrial and agricultural water users [34]. River Basin Authorities and Aimag (provincial) Environment and Tourism Departments (AETDs) have legal authority to review and validate riparian boundaries of water resource lands, establish additional protection zone boundaries, and submit them for approval by the aimag citizen's representative khural (provincial parliament) based on conclusion of Ministry of Environment and Tourism.

Implementation of the 2009 and 2012 water protection laws was hindered by complications in the designation of protection zones, specifically inaccurate and outdated boundary maps and incomplete definitions of "water resources land" and "headwaters of rivers and streams" [35]. 
Therefore, in 2013, the Government Resolution No. 350 "Review of Boundaries" assigned three Ministers to review designations of protection zones, and in 2014 a working group was established to prepare a methodology for the revision of protection zones [36]. WWF-Mongolia represented the working group and drafted a method and guidelines that were discussed and approved by the Minister's Council. Here, we describe the process that followed, beginning with consistent delineation of the riparian zone with a spatial model, followed by review and validation by the local RBA and AETD, and finally approval and legislated protection by aimag khural (provincial parliament). The spatial model was developed as part of a framework for mapping and classifying riverine wetlands called Active River Area developed by Smith et al. [37] and widely applied for conservation planning in North America [38-42], Asia [43], Africa [44], and Australia [45].

\section{Materials and Methods}

Designating water protection zones began with developing a consistent, nationallevel delineation of the riparian zones with a spatial model. This was followed by a participatory process of review, revision, and validation by the RBA and AETDs in seven focal provinces. The seven provinces were chosen for their location relative to river basins that are considered critical for maintaining aquatic habitat, water quality, and connectivity to the Amur River headwaters, Lake Khovsgol and the Yenisey River headwaters, and rivers in the Altai-Sayan ecoregion. Finally, the provincial water protection zones were amended to include the validated riparian areas and were approved by each of the seven provinces khurals (provincial parliaments).

\subsection{Spatial Model}

The initial national delineation of riparian zone was created for a series of terrestrial ecosystem classifications that were developed to support conservation planning [46-49]. The riparian zone delineation is a spatial model based on the local topography of the river channel and valley bottom [37]. The spatial model predicts the extent of floodplain and riparian zone by delineating flat areas immediately adjacent to a stream channel as derived from a digital elevation model (DEM). The result is a predictive delineation of potential floodplains, riverine wetlands and other wetlands adjacent to water bodies, including lakes and palustrine wetlands (Figure 2A,B).

To apply the spatial model, source datasets were a hydrologically conditioned DEM and flow directions, both from HydroSHEDs [50] at 3 arc-second resolution (approximately $90 \mathrm{~m}$ at the equator). The first step was to calculate flow accumulation and delineate stream channels and classify by size of upstream drainage area according to flow accumulation thresholds. The next step calculated the model parameters: (a) slope-weighted distance from the stream channel and (b) elevation change relative to the stream channel. Slopeweighted distance is a function of the cumulative change in slope and distance moving laterally from the stream channel. Elevation change is the difference in elevation between each raster cell and the closest cell in the river channel. In the last step, the floodplain is defined, setting thresholds for the maximum slope-weighted distance and maximum change in elevation. These thresholds are specific to each stream size class, so large river channels are assigned higher thresholds for slope-weighted distance and elevation change. Through multiple iterations, the user adjusts parameters to delineate the area that approximates river floodplains and terraces visible on satellite imagery.

The spatial model was classified by major river basin to distinguish perennial rivers in northern basins, with a temperate climate and relatively higher precipitation and runoff, from southern closed desert basins with relatively lower precipitation and ephemeral stream flow. For example, in perennial river basins in northern Mongolia, the model result identifies river floodplains and riparian areas (Figure 2). In the Gobi Desert basins, the model results are classified as dry riverbeds (sayrs) and wet depressions. These areas lie over shallow groundwater that feeds wells and natural water sources and supports desert plant communities including important habitat species such as Saxaul (Haloxylon ammodendron) and Siberian Elm (Ulmus Pumilla). 


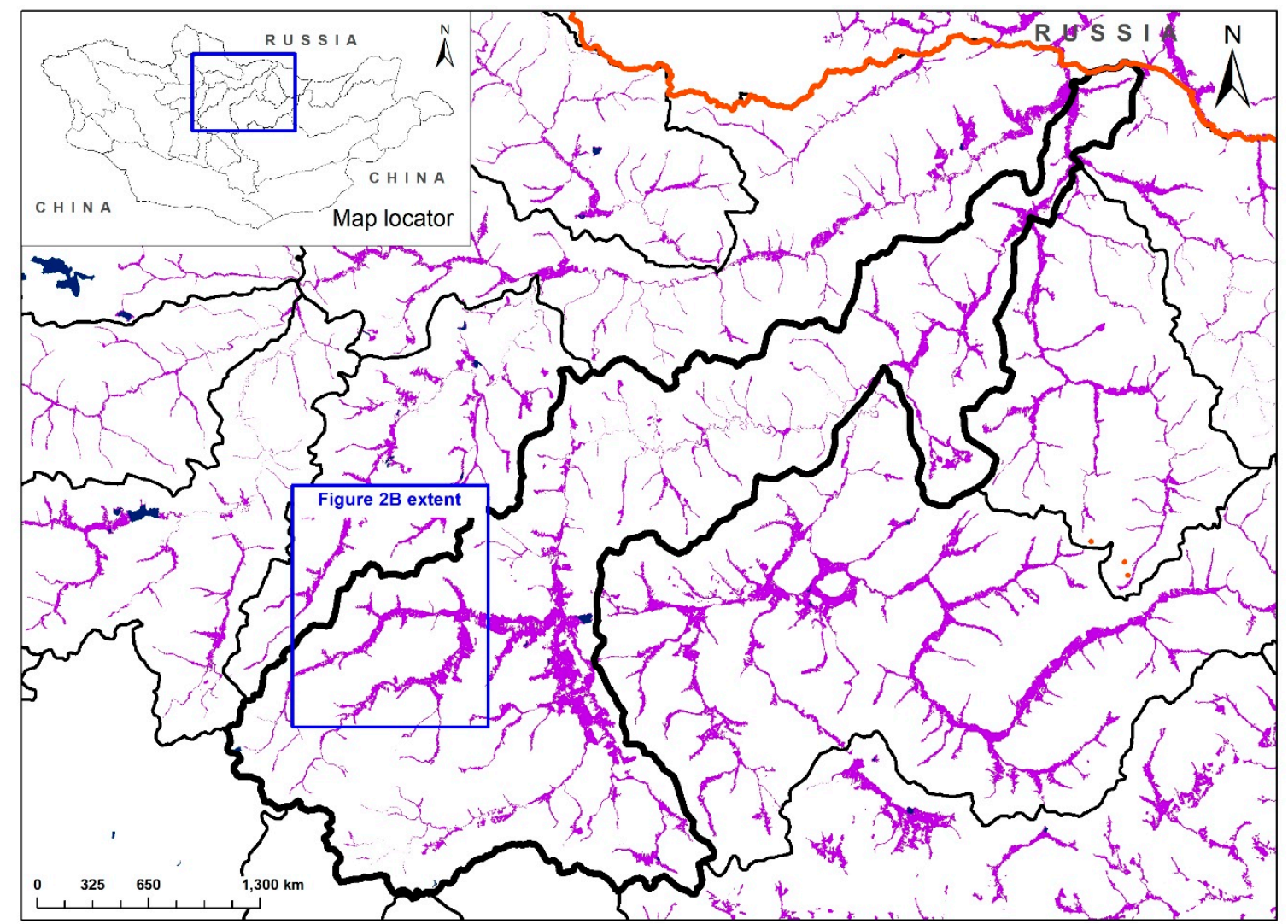

(A)

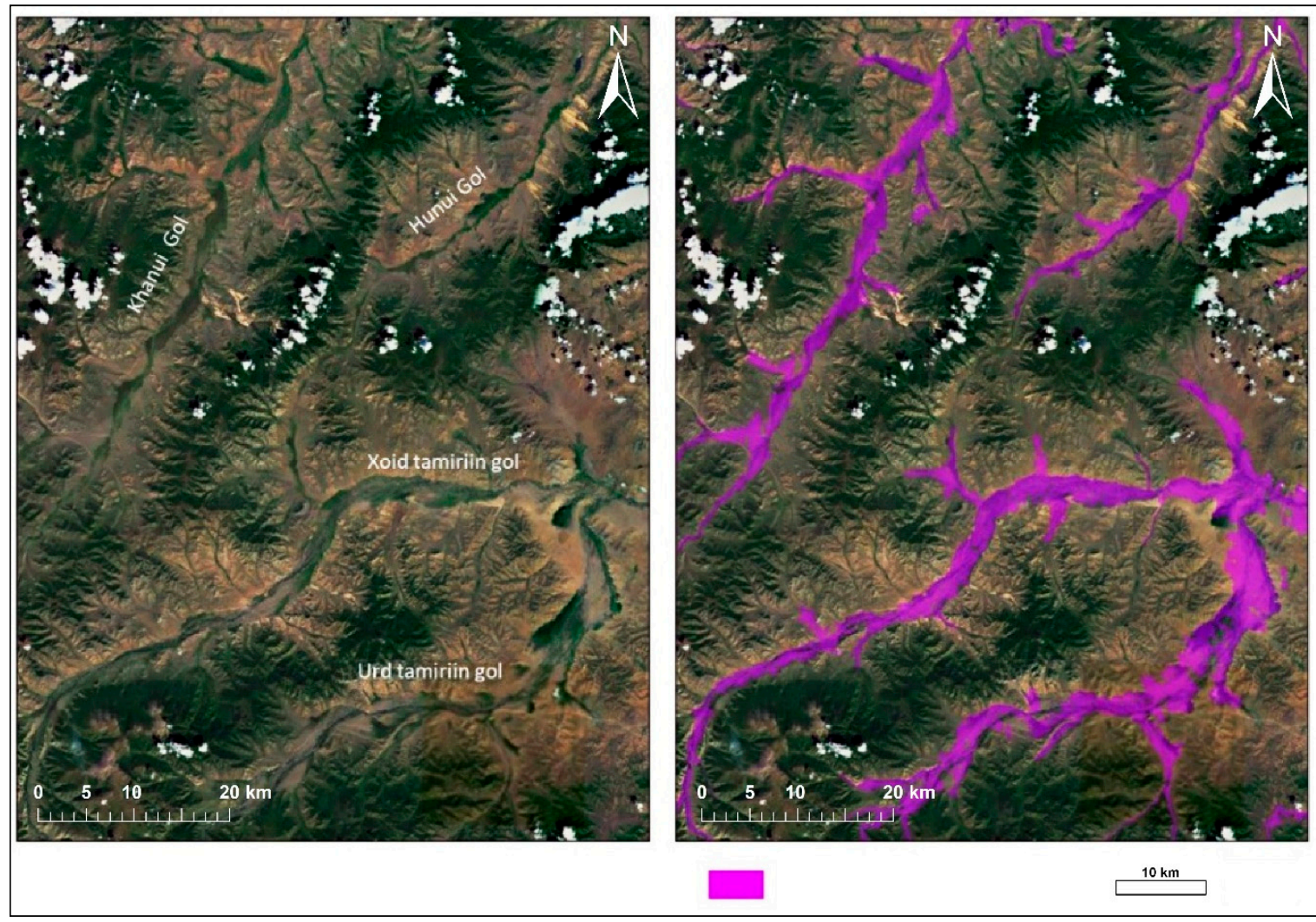

(B)

Figure 2. (A) Spatial model riparian area delineation in the Orkhon-Tamir River Basin. (B) Spatial model result compared with satellite imagery from GoogleEarth. 


\subsection{Review and Validate Jointly with RBAs and AETDs, Approval by Provincial Parliament}

Next, in the seven focal provinces, the spatial model results were reviewed and validated through a participatory process with the RBAs and AETDs. Model results were reviewed and revised through field surveys and comparison with existing maps of water resources, satellite imagery, and a surface water database. Map sources included local surveys with limited geographic extent and national, coarse-scale inventories [51-53] with partial coverage that generally missed smaller tributary rivers. Satellite imagery included Landsat Thematic Mapper (TM) [54], BingMap [55], and GoogleEarth [56]. After review, revision, and validation by the RBA and the AETD, the provincial water protection zones were amended to include the validated riparian areas and were submitted to provincial parliament for approval and legal protection based on conclusion of Ministry of Environment and Tourism. This process was replicated for each of the seven focal provinces.

\section{Results}

The spatial model result identifies 12.9 million hectares of riparian areas and floodplains along the rivers and lakes across Mongolia. In the seven focal provinces, following validation by RBAs and AETDs and approval through provincial parliament resolutions, 8.2 million hectares of riparian areas and adjacent water protection zones have been legally protected from mining and other activities (Figure 3, Table 1). These seven provinces cover $43 \%$ of Mongolia and fully contain nine of 29 river basins. On average, $12 \%$ of the area of the seven provinces has been designated as water protection zones.

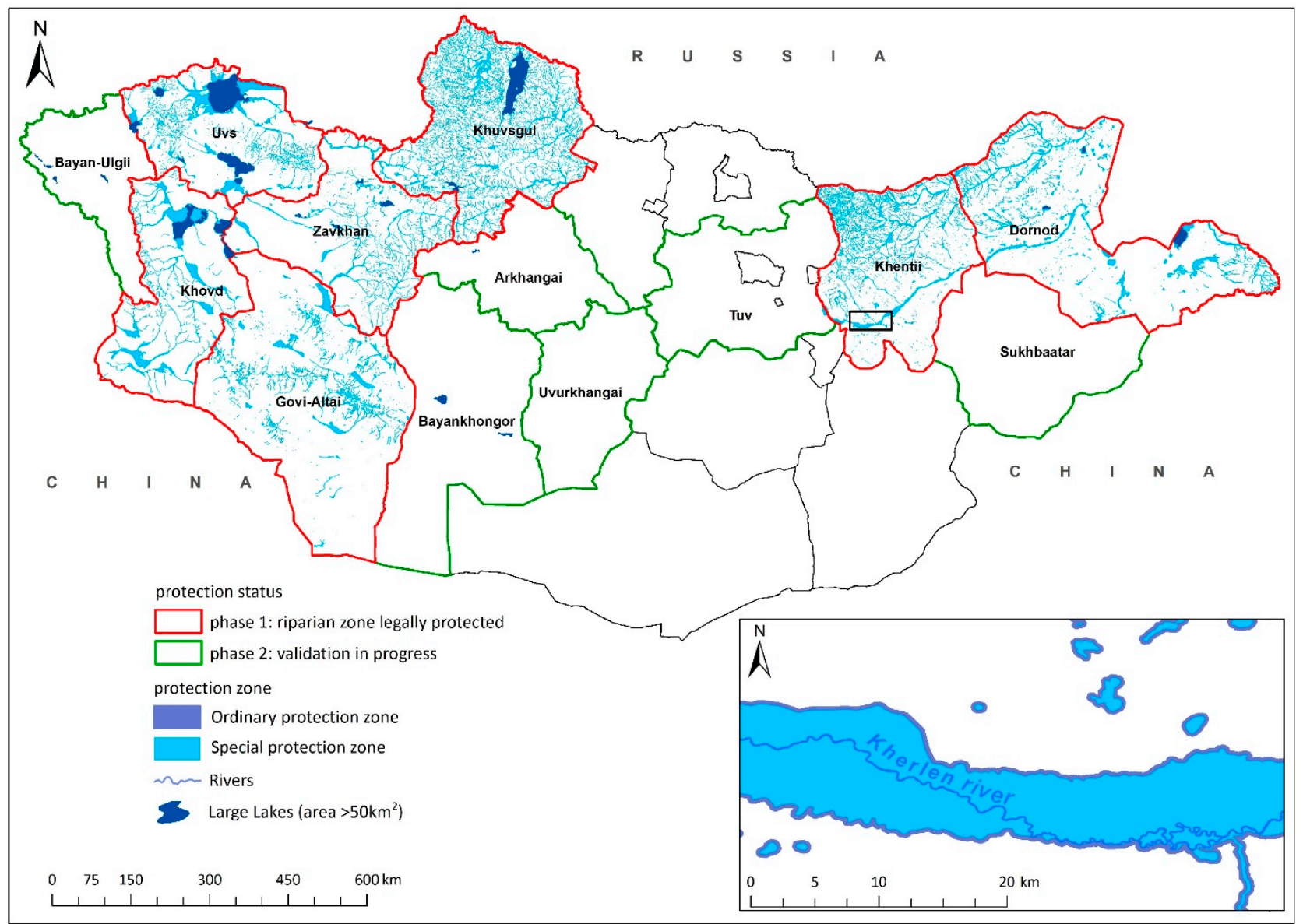

Figure 3. Mongolian provinces (aimags) showing the seven provinces where legal water protection zones have been revised and approved, and the six provinces that are replicating this process. 
Table 1. Approved water protection zones in seven focal provinces (area in hectares).

\begin{tabular}{|c|c|c|c|c|c|c|}
\hline \multirow{2}{*}{ Aimag (Province) } & \multirow{2}{*}{ Aimag Area } & \multicolumn{5}{|c|}{ Approved Legal Water Protection Zone } \\
\hline & & Riparian Area & Special (Strict) & Ordinary (General) & Total & Percent of Aimag \\
\hline $\mathbf{a}$ & $\mathbf{b}$ & c & d & e & $f=c+d+e$ & $\mathbf{f} / \mathbf{b}$ \\
\hline Uvs & $7,088,446$ & $1,167,151$ & 82,521 & 223,375 & $1,473,047$ & $21 \%$ \\
\hline Khovd & $7,777,221$ & 857,610 & 50,779 & 201,532 & $1,109,920$ & $14 \%$ \\
\hline Zavkhan & $8,333,069$ & 363,261 & 67,301 & 218,538 & 649,100 & $8 \%$ \\
\hline Khuvsgul & $10,131,218$ & 655,000 & 336,950 & $1,059,129$ & $2,051,079$ & $20 \%$ \\
\hline Govi-Altai & $14,337,504$ & 338,539 & 75,717 & 229,266 & 643,522 & $4 \%$ \\
\hline Dornod & $12,535,089$ & 861,531 & 61,459 & 244,215 & $1,167,204$ & $9 \%$ \\
\hline Khentii & $8,101,806$ & 541,876 & 279,469 & 368,422 & $1,189,767$ & $15 \%$ \\
\hline Total & $68,304,353$ & $4,784,968$ & 954,195 & $2,544,477$ & $8,283,640$ & $12 \%$ \\
\hline
\end{tabular}

Following this first phase, six other provinces have begun replicating this process. When this second phase is complete, riparian area protection will extend across thirteen provinces that fully contain 17 of Mongolia's 29 river basins.

\section{Discussion}

This study demonstrates a replicable method for delineating riparian areas and its application to implement river protection policy through stakeholder consultation. This has directed the protection of 8.2 million hectares of water bodies and riparian areas in designated water protection zones in seven focal provinces. These areas will be excluded from mining and other activities. Currently, six other provinces are replicating this process. When the second phase is complete, riparian area protections will have been revised and approved in thirteen provinces that cover 73\% of Mongolia. The keys to this success are progressive laws for water protection and establishment of river basin organizations coupled with a data-driven, participatory stakeholder process to direct protection.

Mongolia has made advances in natural resource management, specifically in IWRM and habitat protection. However, durable protection or water resources faces challenges including water governance, monitoring and enforcement, and technical capacity in rural areas [12]. The riparian areas will be protected across the river network, but are still vulnerable to barriers such as water infrastructure.

\subsection{Impacts of Mining to Groundwater Resources}

In the Gobi Desert, water withdrawals to support mining operations could reduce groundwater supplies, affecting wells, natural springs, and vegetation productivity, and ultimately reducing water and forage for livestock and wildlife. In the Inner Mongolian grasslands of China, water withdrawal for coal mining has been identified as the dominant cause of loss of surface water [57]. Because current understanding of the hydrology of this system is limited, it is difficult to estimate the amount, spatial extent or duration of mining-related groundwater impacts.

\subsection{Stakeholder's Interest}

There is a strong interest from local environmental authorities, local government agencies and local people not to mine in riparian zone and to enforce the law relating to water protection. Local people and local authorities strongly appreciate the long-term ecological benefit and ecosystem services from healthy ecosystems rather than short-term economic gain which will have considerable negative impact.

\subsection{Livestock Grazing}

Following Mongolia's transition to a market economy in 1990, pastoral systems and grazing practices have changed $[58,59]$. The number of livestock has nearly tripled, growing to over 66 million animals, in fewer, larger herds [60]. This has resulted in overgrazing, particularly near rural population centers and water sources [61]. Livestock grazing in riparian areas is a significant, widespread threat to the structure and function of riverine wetlands 
for maintaining habitat and water quality. Along many Mongolian rivers, livestock grazing has eroded riverbanks and removed riparian vegetation, causing stream eutrophication and degrading stream habitat $[62,63]$. At least $20-40 \%$ of the area of riparian areas in Mongolia are within $1 \mathrm{~km}$ of a summer herder camp [64]. Livestock grazing practices are not regulated in the water protection zone, however there should be restrictions that help to rehabilitate riparian vegetation and monitoring of land-use and erosion in vulnerable rivers, as well as analysis of the potential impacts of future land use. There is an urgent need for policy and management to protect riparian areas from livestock overgrazing.

\subsection{Climate Change}

Mongolia and Central Asia have been warming over the last 50 years at a faster rate than in the last 1000 years $[65,66]$, producing hotter and more frequent droughts $[67,68]$. This trend is predicted to continue and cause declines in soil moisture and rangeland productivity [69]. Surface- and ground-water sources and stream flows have declined recently across Mongolia [70,71]. These changes to water resources and rangelands will have serious implications for wildlife, pastoralists, and economic development.

\subsection{Landscape Level Mitigation}

Globally, the mitigation hierarchy is a critical mechanism to manage impacts of development by requiring projects to first avoid, then minimize, then restore, and finally offset residual impacts, but the first critical step, avoidance, is often overlooked [72-74]. In 1998, in anticipation of growth in the mining sector, the Mongolian government established a goal of designating 30\% of the country's land and natural habitats as national and local protected areas $[75,76]$. Mongolia has developed a national mitigation framework to implement this protection goal and apply the mitigation hierarchy [77]. The framework is based on stakeholder-driven, landscape level conservation plans that produced a portfolio of priority conservation areas designed to meet 30\% representation goals for terrestrial ecosystems and minimize conflict with competing economic values [46-49].

The national mapped classification of riparian areas is a key component of the national ecosystem classification on which the conservation portfolio and the mitigation framework are based. This has directed the protection of 177,000 sq. km in new protected areas and led to an amended Environmental Impact Assessment (EIA) offset law that requires biodiversity offsets for all mining and oil development projects [78]. The law requires companies to calculate minimum offset cost according to potential impacts to ecosystems, with higher compensation for impacts to rare and highly productive ecosystems including riverine wetlands.

Given the impacts of mining on river systems and the pace of mining expansion in Mongolia, effective mitigation of impacts is an urgent issue. Mongolia's progressive laws for conservation of water resources and commitment to habitat protection provide the legal and policy basis to effectively implement durable, legal protection of rivers through a data-driven, participatory process.

Author Contributions: Conceptualization, P.S., C.B. and M.H.; methodology, S.D., M.H. and P.S.; validation, P.S. and S.B.; formal analysis, S.D., M.H., S.B. and P.S.; investigation, P.S.; resources, S.D., M.H., S.B.; data curation, P.S. and S.D.; writing-original draft preparation, S.D., M.H. and P.S.; writing-review and editing, C.-O.B., B.Z., S.D., C.B., P.S. and M.H.; visualization, S.P. and M.H.; supervision, P.S. and C.B.; project administration, P.S. and C.B.; funding acquisition, P.S. and C.B. All authors have read and agreed to the published version of the manuscript.

Funding: The model results presented in this manuscript are analyzed with the expert team headed by WWF-Mongolia, funded by Ministry of Environment and Green Development (MEGD), grant number MEGD/2014/K7, and field validation of riparian areas are funded by WWF-Mongolia, grant number ASER40000796/AHEC004107.

Institutional Review Board Statement: Not applicable.

Informed Consent Statement: Not applicable. 
Data Availability Statement: Please refer to suggested Data Availability Statements in section "MDPI Research Data Policies" at https://www.mdpi.com/ethics.

Acknowledgments: We are indebted to the Local River Basin Authorities and provincial Environment and Tourism Departments and local stakeholders who actively participated and supported in the validation and approval processes. We thank WWF-Mongolia for leadership and the opportunity to collaborate. Our sincere thanks to D. Enkhbat, Yo. Onon (MEGD), D. Galbadrakh (TNC-Mongolia) for critical comments and collaboration, and to M. Urtnasan, Z. Nyambayar (Geography Institute, MAS), P. Magsarjav (Tuul RBA) and James Oakleaf (TNC-US) for technical support with data analysis.

Conflicts of Interest: The authors declare no conflict of interest.

\section{References}

1. Tickner, D.; Opperman, J.J.; Abell, R.; Acreman, M.; Arthington, A.H.; Bunn, S.E.; Cooke, S.J.; Dalton, J.; Darwall, W.; Edwards, G.; et al. Bending the curve of global freshwater biodiversity loss: An emergency recovery plan. Bioscience 2020, 70, 330-342. [CrossRef] [PubMed]

2. Reid, A.J.; Carlson, A.K.; Creed, I.F.; Eliason, E.J.; Gell, P.A.; Johnson, P.T.; Kidd, K.A.; MacCormack, T.J.; Olden, J.D.; Ormerod, S.J.; et al. Emerging threats and persistent conservation challenges for freshwater biodiversity. Biol. Rev. 2019, 94, 849-873. [CrossRef] [PubMed]

3. Harrison, I.; Abell, R.; Darwall, W.; Thieme, M.L.; Tickner, D.; Timboe, I. The freshwater biodiversity crisis. Science 2018, 362, 1369. [PubMed]

4. Naiman, R.J.; Decamps, H. The ecology of interfaces: Riparian zones. Annu. Rev. Ecol. Syst. 1997, 28, 621-658. [CrossRef]

5. Chin, A. Urban Transformation of River Landscapes in a Global Context. Geomorphology 2006, 79, 460-487. [CrossRef]

6. Davidson, N.C. How much wetland has the world lost? Long-term and recent trends in global wetland area. Mar. Freshw. Res. 2014, 65, 934-941. [CrossRef]

7. Dixon, M.J.R.; Loh, J.; Davidson, N.C.; Beltrame, C.; Freeman, R.; Walpole, M. Tracking global change in ecosystem area: The Wetland Extent Trends index. Biol. Conserv. 2016, 193, 27-35. [CrossRef]

8. Almond, R.E.A.; Grooten, M.; Petersen, T. WWF (2020) Living Planet Report_Bending the Curve of Biodiversity Loss; WWF: Gland, Switzerland, 2020.

9. Reis, V.; Hermoso, V.; Hamilton, S.K.; Bunn, S.E.; Linke, S. Conservation planning for river-wetland mosaics: A flexible spatial approach to integrate floodplain and upstream catchment connectivity. Biol. Conserv. 2019, 236, 356-365. [CrossRef]

10. Abell, R.; Allan, J.D.; Lehner, B. Unlocking the potential of protected areas for freshwaters. Biol. Conserv. 2007, 134, 48-63. [CrossRef]

11. Suzuki, Y. Conflict between Mining Development and Nomadism in Mongolia. In The Mongolian Ecosystem Network. Ecological Research Monographs; Yamamura, N., Fujita, N., Maekawa, A., Eds.; Springer: Tokyo, Japan, 2013.

12. Karthe, D.; Hofmann, J.; Ibisch, R.; Heldt, S.; Westphal, K.; Menzel, L.; Avlyush, S.; Malsy, M. Science-based IWRM implementation in a data-scarce central Asian region: Experiences from a research and development project in the Kharaa River Basin, Mongolia. Water 2015, 7, 3486-3514. [CrossRef]

13. Simonov, E.A.; Nikitina, O.I.; Egidarev, E.G. Freshwater Ecosystems versus Hydropower Development: Environmental Assessments and Conservation Measures in the Transboundary Amur River Basin. Water 2019, 11, 1570. [CrossRef]

14. Nikitina, O.I.; Dubinina, V.G.; Bolgov, M.V.; Parilov, M.P.; Parilova, T.A. Environmental Flow Releases for Wetland Biodiversity Conservation in the Amur River Basin. Water 2020, 12, 2812. [CrossRef]

15. Nyambayar, B.; Tseveenmyadag, N. Directory of Important Bird Areas in Mongolia: Key Sites for Conservation; Wildlife Science and Conservation Center: Ulaanbaatar, Mongolia, 2009; pp. 1-103.

16. Olson, D.M.; Dinerstein, E. The Global 200: A representation approach to conserving the Earth's most biologically valuable ecoregions. Conserv. Biol. 1998, 12, 502-515. [CrossRef]

17. Millenium Ecosystem Assessment. Altai-Sayan Ecoregion Subglobal Assessment Report. In Ecosystems and Human Well-BeingSynthesis: A Report of the Millennium Ecosystem Assessment; Reid, W.V., Mooney, H.A., Cropper, A., Capistrano, D., Carpenter, S.R., Chopra, K., Dasgupta, P., Dietz, T., Duraiappah, A.K., Hassan, R., et al., Eds.; World Wide Fund for Nature Russian Programme: Moskov, Russia, 2005.

18. Batsaikhan, N.; Buuveibaatar, B.; Chimed, B.; Enkhtuya, O.; Galbrakh, D.; Ganbaatar, O.; Lkhagvasuren, B.; Nandintsetseg, D.; Berger, J.; Calabrese, J.M.; et al. Conserving the world's finest grassland amidst ambitious national development. Conserv. Biol. 2014, 28, 1736-1739. [CrossRef] [PubMed]

19. Hoekstra, J.M.; Boucher, T.M.; Ricketts, T.H.; Roberts, C. Confronting a biome crisis: Global disparities of habitat loss and protection. Ecol. Lett. 2005, 8, 23-29. [CrossRef]

20. Allan, J.; Venter, O.; Watson, J.E.M. Temporally inter-comparable maps of terrestrial wilderness and the Last of the Wild. Sci. Data 2017, 4, 170187. [CrossRef] [PubMed]

21. Kennedy, C.M.; Oakleaf, J.R.; Theobald, D.M.; Baruch-Mordo, S.; Kiesecker, J. Managing the middle: A shift in conservation priorities based on the global human modification gradient. Glob. Chang. Biol. 2019, 25, 811-826. [CrossRef]

22. Hijmans, R.J.; Cameron, S.E.; Parra, J.L.; Jones, P.G.; Jarvis, A. Very high resolution interpolated climate surfaces for global land areas. Int. J. Climatol. 2005, 25, 1965-1978. [CrossRef] 
23. Vandandorj, S.; Gantsetseg, B.; Boldgiv, B. Spatial and temporal variability in vegetation cover of Mongolia and its implications. J. Arid Land 2015, 7, 450-461. [CrossRef]

24. Mongolia 2018 EITI Report: Extractive Industries Transparency Initiative. Available online: https://eiti.org/document/mongolia2018-eiti-report (accessed on 20 October 2020).

25. Stubblefield, A.; Chandra, S.; Eagan, S.; Tuvshinjargal, D.; Davaadorzh, G.; Gilroy, D.; Sampson, J.; Thorne, J.; Allen, B.; Hogan, Z. Impacts of gold mining and land use alterations on the water quality of central Mongolian rivers. Integr. Environ. Assess. Manag. Int. J. 2005, 1, 365-373. [CrossRef]

26. National Research Council. Riparian Areas: Functions and Strategies for Management; The National Academies Press: Washington, DC, USA, 2002.

27. Tumurchudur, S.; Jadambaa, D. Integrated Natural Resource Management in the Baikal Basin Transboundary Ecosystem; UNDP-GEF Project: Ulaanbaatar, Mongolia, 2012; pp. 1-35.

28. Yadamsuren, O.; Morse, J.C.; Hayford, B.; Gelhaus, J.K.; Adler, P.H. Macroinvertebrate community responses to land use: A trait-based approach for freshwater biomonitoring in Mongolia. Hydrobiologia 2020, 1-16. [CrossRef]

29. Houdret, A.; Dombrowsky, I.; Horlemann, L. The institutionalization of River Basin Management as politics of scale-Insights from Mongolia. J. Hydrol. 2014, 519, 2392-2404. [CrossRef]

30. Government of Mongolia. Resolution \#174: Designating prohibited boundaries of water protection zone. In Government News; Government of Mongolia: Ulaanbaatar, Mongolia, 2011.

31. Mongolian Government. Resolution \#194. Available online: https:/ / www.legalinfo.mn/law/details/8732 (accessed on 20 October 2020).

32. Ministry of Environment and Tourism of Mongolia. Ministry of Construction and Urban Development of Mongolia. Ministerial degrees \#A-230/127, ensure the water protection regimes for protection zones. In Compilation of Water Regulation, 1st ed.; Myagmar, S., Ed.; Ministry of Environment and Tourism: Ulaanbaatar, Mongolia, 2020; pp. 468-474.

33. Government of Mongolia. Resolution \#254: Establish River Basin Authority, In Compilation of Water regulation, 1st ed.; Myagmar, S., Ed.; Ministry of Environment and Tourism: Ulaanbaatar, Mongolia, 2020; pp. 277-278.

34. Fan, M. Achieving Sustainable Integrated Water Resources Management in Mongolia: The Role of River Basin Organizations. ADB Briefs 2020, 138, 1-6.

35. Ministry of Environment and Green Development of Mongolia and Professional Inspection Agency of Mongolia. Assessment Report of law enforcement on Prohibiting Mineral Exploration and Mining within Protection Zones of Headwaters for Rivers and Streams and Water and Forest Resources Land; Ministry of Environment and Green Development and Professional Inspection Agency: Ulaanbaatar, Mongolia, 2012; pp. 1-14.

36. Ministry of Environment and Tourism of Mongolia. Ministerial Degree \#A-38: Establish the Working Group to Develop Methodology for Revision of Protection Zones; Ministry of Environment and Tourism of Mongolia: Ulaanbaatar, Mongolia, 2014.

37. Smith, M.P.; Schiff, R.; Olivero, A.; MacBroom, J.G. The Active River Area: A Conservation Framework for Protecting Rivers and Streams; The Nature Conservancy: Boston, MA, USA, 2008.

38. Olivero, S.A.; Barnett, A.; Anderson, M.G. A Stream Classification for the Appalachian Region; The Nature Conservancy, Eastern Regional Office: Boston, MA, USA, 2015.

39. Martin, E.H.; Apse, C.D.S. Northeast Aquatic Connectivity: An Assessment of Dams on Northeastern Rivers; The Nature Conservancy, Eastern Freshwater Program: Brunswick, ME, USA, 2011.

40. Nussey, P.; Noseworthy, J. The Active River Area for the Northern Appalachian-Acadian Region of Canada; Nature Conservancy of Canada, Atlantic Regional Office: Fredericton, NB, Canada, 2020.

41. Iachetti, P.J.; Floberg, G.; Wilhere, K.; Ciruna, D.; Markovic, J.; Lewis, M.; Heiner, G.; Kittel, R.; Crawford, S.; Farone, S.; et al. North Cascades and Pacific Ranges Ecoregional Assessment; Nature Conservancy of Canada: Victoria, BC, Canada, 2006.

42. Pryce, B.P.; Iachetti, G.; Wilhere, K.; Ciruna, J.; Floberg, R.; Crawford, R.; Dye, M.; Fairbarns, S.; Farone, S.; Ford, M.; et al. Okanagan Ecoregional Assessment; The Nature Conservancy of Canada: Victoria, BC, Canada, 2006.

43. Heiner, M.; Batsaikhan, N.; Galbadrakh, D.; Bayarjargal, Y.; Zumberelmaa, D.; Ariungerel, D.; Evans, J.; von Werden, H.; Kiesecker, J. Towards a National Spatial Model to Map Terrestrial Ecosystems in Mongolia: A Pilot Study in the Gobi Desert Region. Proceedings of Building Resilience of Mongolian Rangelands: A Trans-disciplinary Research Conference, Ulaanbaatar, Mongolia, 9-10 June 2015.

44. Goldstein, J.H.; Tallis, H.; Cole, A.; Schill, S.; Martin, E.; Heiner, M.; Paiz, M.C.; Aldous, A.; Apse, C.; Nickel, B. Spatial planning for a green economy: National-level hydrologic ecosystem services priority areas for Gabon. PLoS ONE 2017, 12, e0179008. [CrossRef] [PubMed]

45. Heiner, M.; Hinchley, D.; Fitzsimons, J.; Weisenberger, F.; Bergmann, W.; McMahon, T.; Milgin, J.; Nardea, L.; Oakleaf, J.; Parriman, D.; et al. Moving from reactive to proactive development planning to conserve Indigenous community and biodiversity values. Environ. Impact Assess. Rev. 2019, 74, 1-13. [CrossRef]

46. The Nature Conservancy Mongolia Country Program. Identifying Conservation Priorities in the Face of Future Development: Applying Development by Design in the Grasslands of Mongolia; The Nature Conservancy: Ulaanbaatar, Mongolia, 2011.

47. The Nature Conservancy Mongolia Country Program. Identifying Conservation Priorities in the Face of Future Development: Applying Development by Design in the Mongolian Gobi Desert; The Nature Conservancy: Ulanbaatar, Mongolia, 2013. 
48. The Nature Conservancy Mongolia Country Program. Identifying Conservation Priorities in the Face of Future Development: Applying Development by Design in Western Mongolia: Mongol Altai Mountains, Great Lakes Depression, and Lakes Valley; The Nature Conservancy: Ulaanbaatar, Mongolia, 2017.

49. The Nature Conservancy Mongolia Country Program. Identifying Conservation Priorities in the Face of Future Development: Applying Development by Design in the Khangai and Khuvsgul; The Nature Conservancy: Ulaanbaatar, Mongolia, 2017.

50. Lehner, B.; Verdin, K.; Jarvis, A. New global hydrography derived from space borne elevation data. Eos Trans. Am. Geophys. Union 2008, 89, 93-94. [CrossRef]

51. Classifications of uNified Land Territory: Boundaries of Water Resources Land. Available online: https://gazar.gov.mn/ (accessed on 15 September 2014).

52. Ministry of Environment and Tourism of Mongolia. Report for National Surface Water Inventory; Ministry of Environment and Tourism of Mongolia: Ulaanbaatar, Mongolia, 2011.

53. Water Database of Mongolia. Available online: https:/ / eic.mn/water/ (accessed on 4 April 2018).

54. Landsat Thematic Mapper (TM). Available online: http:/ / earthexplorer.usgs.gov (accessed on 5 September 2020).

55. BingMap. Available online: https://www.bing.com/maps (accessed on 5 August 2017).

56. GoogleEarth. Available online: https:/ / earth.google.com/web/ (accessed on 13 August 2017).

57. Tao, S.; Fang, J.; Zhao, X.; Zhao, S.; Shen, H.; Hu, H.; Tang, Z.; Wang, Z.; Guo, Q. Rapid loss of lakes on the Mongolian Plateau. Proc. Natl. Acad. Sci. USA 2015, 112, 2281-2286. [CrossRef]

58. Fernandez-Gimenez, M.E.; Batbuyan, B. Law and Disorder: Local Implementation of Mongolia's Land Law. Dev. Chang. 2004, 35, 141-166. [CrossRef]

59. Fernandez-Gimenez, M.E. The Effects of Livestock Privatization on Pastoral Land Use and Land Tenure in Post-Socialist Mongolia. Nomadic Peoples 2001, 5, 49-66. [CrossRef]

60. National Statistics Office of Mongolia. Mongolian Statistical Yearbook; National Statistics Office of Mongolia: Ulaanbaatar, Mongolia, 2018.

61. Stumpp, M.; Wesche, K.; Retzer, V.; Miehe, G. Impact of Grazing Livestock and Distance from Water Source on Soil Fertility in Southern Mongolia. Mt. Res. Dev. 2005, 25, 244-251. [CrossRef]

62. Maasri, A.; Gelhaus, J. The new era of the livestock production in Mongolia: Consequences on streams of the Great Lakes Depression. Sci. Total Environ. 2011, 409, 4841-4846. [CrossRef] [PubMed]

63. Karthe, D.; Heldt, S.; Houdret, A.; Borchardt, D. IWRM in a country under rapid transition: Lessons learnt from the Kharaa River Basin, Mongolia. Environ. Earth Sci. 2015, 73, 681-695. [CrossRef]

64. Jamsranjav, C.; Reid, R.S.; Fernández-Giménez, M.E.; Tsevlee, A.; Yadamsuren, B.; Heiner, M. Applying a dryland degradation framework for rangelands: The case of Mongolia. Ecol. Appl. 2018, 28, 622-642. [CrossRef] [PubMed]

65. Chen, F.; Wang, J.; Jin, L.; Zhang, Q.; Li, J.; Chen, J. Rapid warming in mid-latitude central Asia for the past 100 years. Front. Earth Sci. China 2009, 3, 42. [CrossRef]

66. Davi, N.K.; D'Arrigo, R.; Jacoby, G.C.; Cook, E.R.; Anchukaitis, K.J.; Nachin, B.; Rao, M.P.; Leland, C. A long-term context (931-2005 CE) for rapid warming over Central Asia. Quat. Sci. Rev. 2015, 121, 89-97. [CrossRef]

67. Pederson, N.; Hessl, A.E.; Baatarbileg, N.; Anchukaitis, K.J.; Di Cosmo, N. Pluvials, droughts, the Mongol Empire, and modern Mongolia. Proc. Natl. Acad. Sci. USA 2014, 111, 4375-4379. [CrossRef]

68. Batima, P.; Natsagdorj, L.; Gombluudev, P.; Erdenetsetseg, B. Observed climate change in Mongolia. Assess Imp. Adapt. Clim. Chang. Work Pap. 2005, 12, 1-26.

69. Angerer, J.; Han, G.; Fujisaki, I.; Havstad, K. Climate change and ecosystems of Asia with emphasis on Inner Mongolia and Mongolia. Rangelands 2008, 30, 46-51. [CrossRef]

70. Ministry of Environment and Tourism of Mongolia. Mongolia Assessment Report on Climate Change; Ministry of Environment and Tourism of Mongolia: Ulaanbaatar, Mongolia, 2009.

71. Fassnacht, S.R.; Sukh, T.; Fernandez-Gimenez, M.; Batbuyan, B.; Venable, N.B.H.; Laituri, M.; Adyabadam, G. Local understanding of hydro-climatic changes in Mongolia. Proceedings of the Cold Region Hydrology in a Changing Climate of the IUGG, Melbourne, Australia, July 2011; IAHS Publ.: Melbourne, Australia, 2011; Volume 346, pp. 120-129.

72. Clare, S.; Krogman, N.; Foote, L.; Lemphers, N. Where is the avoidance in the implementation of wetland law and policy? Wetl. Ecol. Manag. 2011, 19, 165-182. [CrossRef]

73. Villarroya, A.; Barros, A.C.; Kiesecker, J. Policy development for environmental licensing and biodiversity offsets in Latin America. PLoS ONE 2014, 9, e107144. [CrossRef]

74. Phalan, B.; Hayes, G.; Brooks, S.; Marsh, D.; Howard, P.; Costelloe, B.; Vira, B.; Kowalska, A.; Whitaker, S. Avoiding impacts on biodiversity through strengthening the first stage of the mitigation hierarchy. Oryx 2018, 52, 316-324. [CrossRef]

75. State Great Parliament of Mongolia. Master Plan for Protected Areas; State Great Parliament of Mongolia: Ulaanbaatar, Mongolia, 1998.

76. State Great Parliament of Mongolia. Green Development Policy; State Great Parliament of Mongolia: Ulaanbaatar, Mongolia, 2014.

77. Heiner, M.; Galbadrakh, D.; Batsaikhan, N.; Bayarjargal, Y.; Oakleaf, J.; Tsogtsaikhan, B.; Evans, J.; Kiesecker, J. Making space: Putting landscape-level mitigation into practice in Mongolia. Conserv. Sci. Pract. 2019, 1, e110. [CrossRef]

78. Law on Environmental Impact Assessment. Available online: https://www.legalinfo.mn/law/details/8665 (accessed on 20 October 2020). 